Reprinted with permission from: Weed Science. 1992. 40(1):101-105.

Published and copyrighted by: Weed Science Society of America. http://www.wssa.net

\title{
Fluroxypyr absorption and translocation in leafy spurge (Euphorbia esula) ${ }^{1}$
}

\author{
RODNEY G. LYM \\ Assoc. Prof., Crop and Weed Sci. Dep., N.D. State Univ., Fargo, ND 58105.
}

\begin{abstract}
:
Absorption and translocation of ${ }^{14} \mathrm{C}$-fluroxypyr were determined for leafy spurge at various growth stages, under differing relative humidity and temperature conditions, and when applied with picloram or 2,4-D. Absorption of ${ }^{14} \mathrm{C}$-fluroxypyr was greater in vegetative plants $(39 \%)$ than in flowering or postflowering plants $(25 \%)$, while total translocated to roots averaged $2 \%$ of applied herbicide regardless of growth stage. Greater ${ }^{14} \mathrm{C}$-fluroxypyr absorption and translocation occurred in plants exposed to high relative humidity $(>90 \%)$ compared to low humidity $(<30 \%)$ for 6 hours or longer following treatment. Absorption and translocation to roots was independent of temperature $\left(18\right.$ or $\left.24^{\circ} \mathrm{C}\right)$. Absorption and translocation declined by $50 \%$ when applied with picloram or $2,4-\mathrm{D}$. However, absorption and translocation of ${ }^{14} \mathrm{C}$-picloram or ${ }^{14} \mathrm{C}-2,4-\mathrm{D}$ were not affected by fluroxypyr. Fluroxypyr would likely be used in a leafy spurge control program only during environmental conditions adverse to control with picloram such as unseasonably warm or cold temperatures or in areas with a high water table. Nomenclature: Fluroxypyr, 4-amino-3,5-dichloro-6fluoro-2-pyridyloxyacetic acid; picloram, 4-amino-3,5,6-trichloro-2pyridinecarboxylic acid; 2,4-D, (2,4-dichlorophenoxy)acetic acid; leafy spurge, Euphorbia esula L \#² EPHES.
\end{abstract}

\section{Additional index words:}

Picloram, 2,4-D, herbicide combination, perennial weed, temperature, relative humidity, EPHES.

\footnotetext{
${ }^{1}$ Received for publication October 9, 1991, and in revised form August 28, 1991. Published with approval of the Director, Agric. Exp. Stn., N.D. State Univ. as J. Art. No. 1957.

${ }^{2}$ Letters following this symbol are a WSSA-approved computer code from Composite List of Weeds, Revised 1989. Available from WSSA, 309 West Clark Street, Champaign, IL 61820.
} 


\section{Introduction}

Leafy spurge is a long-lived perennial weed in the Northern Great Plains that continues to spread despite major control programs in several states. Leafy spurge has spread rapidly from an infestation of 170,000 ha in North Dakota in 1973 to over 490,000 ha in 1990 (12). The current infestation costs North Dakota over \$23 million annually in direct loss in hay and beef cattle production and nearly $\$ 75$ million annually in lost retail trade (15).

Picloram is the most effective herbicide for control of leafy spurge $(4,5,6)$. However, picloram cannot be used near trees, surface water, or in areas with groundwater near the soil surface because of its long soil residual and high water solubility (7).

Fluroxypyr, a pyridine-based herbicide, is structurally similar to picloram but with shorter soil residual and lower water solubility (14). The soil half-life of fluroxypyr in North Dakota is approximately 50 days compared to 105 days or more for picloram. Water solubility at $25^{\circ} \mathrm{C}$ is $1 \mathrm{ppm}$ for fluroxypyr versus $450 \mathrm{ppm}$ for picloram $(14,16)$. Also, fluroxypyr residues are strongly adsorbed to soil particles and remain in the top 10 $\mathrm{cm}$ of the soil profile. Thus, fluroxypyr is unlikely to contaminate groundwater when applied at general use rates of $0.5 \mathrm{~kg} \mathrm{ae} \mathrm{ha}^{-1}$ or less (14).

Fluroxypyr has a narrower weed control spectrum than picloram (14) but will control leafy spurge (17). Fluroxypy applied with picloram or 2,4-D occasionally has given better leafy spurge control than fluroxypyr alone $(3,10)$. Fluroxypyr or picloram at $0.56 \mathrm{~kg} \mathrm{ha}^{-1}$ applied alone annually for 3 years provided $40 \%$ control 12 months after the last treatment, compared to fluroxypyr plus picloram at 0.28 plus $0.28 \mathrm{~kg} \mathrm{ha}^{-1}$, which averaged $60 \%$ control.

Fluroxypyr applied alone or with other herbicides may be useful in a long-term annual treatment program for leafy spurge control. The purpose of this research was to evaluate the absorption and translocation of fluroxypyr in leafy spurge as affected by plant growth stage, environment, and application with picloram or 2,4-D to determine the optimum conditions for leafy spurge control with fluroxypyr.

\section{Materials and methods}

\section{Plant propagation}

Leafy spurge plants were propagated from one accession (1984 ND 001) ${ }^{3}$ that originally was obtained from a natural infestation near Fargo, ND. Stem tips about 3-cm long were cut from the parent clones. Ali leaves but die upper three to four were removed, and the basal stem was dipped in a commercial mixture of $0.2 \%$ NAA (1-naphthaleneacetic acid). Each cutting was planted into a 4-cm-diameter by 20 -cm-deep conical pot which contained a potting medium of peat, perlite, and vermiculite ${ }^{4}$. Plants were grown in the

\footnotetext{
${ }^{3}$ Registry of leafy spurge accessions maintained by David G. Davis, USDA Biosciences Res. Lab., Fargo, ND 58105.

${ }^{4}$ Sunshine Mix No. 1. Fisons Western Corp., Downers Grove, IL 60515.
} 
greenhouse at 24 to $27^{\circ} \mathrm{C}$ with supplemental light $\left(400 \mu \mathrm{E} \mathrm{m} \mathrm{m}^{-2} \mathrm{~s}^{-1}\right.$ photosynthetic photon flux density) to obtain a 16-hour light and 8-hour dark photoperiod.

\section{Growth stage}

Approximately 6 weeks after planting, top growth was removed at the soil surface, and one stem per pot was allowed to regrow for 30,60 or 90 days to provide plants in the vegetative, flowering, and postflowering growth stages, respectively. Cuttings were started periodically to obtain uniformly sized plants in each growth stage.

The leaf to be treated with ${ }^{14} \mathrm{C}$-herbicide was midway on the stem of each plant, and was enclosed with a paper envelope. The entire plant was then treated with fluroxypyr 1-methylheptyl ester at $0.56 \mathrm{~kg} \mathrm{ha}^{-1}$ applied with a moving-nozzle pot sprayer delivering $47 \mathrm{~L} \mathrm{ha}^{-1}$ at $240 \mathrm{kPa}$. The protective envelope was removed and the leaf was treated with $1700 \mathrm{~Bq}$ of uniformly pyridyl-ring-labeled ${ }^{14} \mathrm{C}$-fluroxypyr (specific activity $969.4 \mathrm{MBq}$ mmole $^{-1}$ ) plus enough commercially formulated fluroxypyr to obtain a final concentration of $0.56 \mathrm{~kg} \mathrm{ha}^{-1}$. The herbicide solution with $0.125 \%$ by volume nonionic surfactant ${ }^{5}$ was applied in one $10 \mu \mathrm{l}$ droplet over the leaf.

Plants were harvested 72 hours after treatment and separated into the treated leaf, stem and leaves above or below the treated leaf, and roots. Roots were washed with water to remove the potting medium and were sectioned into 0 - to 4-, 4- to 8-, and 8- to $16-\mathrm{cm}$ depths. The treated leaf was rapidly dipped 10 times into $15 \mathrm{ml}$ of scintillation fluid ' $\mathrm{A}$ ' $\left\{1: 1\right.$ by volume toluene:ethanol plus $5 \mathrm{~g} \mathrm{~L}^{-1} \mathrm{PPO}(2,5$ diphenyloxazole $\left.)\right]$ and $0.5 \mathrm{~g} \mathrm{~L}^{-1}$ dimethyl-POPOP [1,4-bis-2-(4-methyl-5-phenyloxazolyl)benzene]\} to remove unabsorbed ${ }^{14} \mathrm{C}$-herbicide, which was quantified using liquid scintillation spectrometry. Preliminary experiments found this leaf wash method effectively solubilized the ${ }^{14} \mathrm{C}$-herbicides but did not excessively solubilize die cuticle waxes. Plant parts were dried at $60^{\circ} \mathrm{C}$ for 24 hours, and root and shoot sections were ground in a wiley mill (No. 10 mesh) and weighed.

The treated leaf and two or more 120 - to $150-\mathrm{mg}$ root or shoot subsamples equaling at least $10 \%$ of the sample weight were each combusted in a biological tissue oxidizer ${ }^{6}$. The ${ }^{14} \mathrm{CO}_{2}$ was collected in $15 \mathrm{ml}$ of scintillation fluid 'B' POPOP (10:7:3 by volume toluene:2-methoxyethanol: ethanolamine plus $5.0 \mathrm{~g} \mathrm{~L}^{-1}$ PPO and $0.5 \mathrm{~g} \mathrm{~L}^{-1}$ dimethyl POPOP and was assayed using liquid scintillation spectrometry. Oxidizer efficiency was determined using methyl $-{ }^{14} \mathrm{C}$-methacrylate, and liquid scintillation counting efficiency was determined using an external standards ratio and standard corrections. Percent recovery averaged $95 \%$ for all experiments.

\section{Humidity}

Leafy spurge plants were transferred from the greenhouse to growth chambers 48 hours before treatment. Relative humidity in the greenhouse ranged from 40 to $60 \%$.

\footnotetext{
${ }^{5}$ Surfactant WK (dodecyl ether of polyethylene glycol). E.I. DuPont de Nemours and Co., Wilmington. DE.

${ }^{6}$ Model OX100. R. J. Harvey Instrument Corp., Hillsdale, NJ.
} 
Growth chamber conditions were either high (90 to $95 \%$ ) or low (20 to $30 \%$ ) relative humidity at $30 / 18^{\circ} \mathrm{C}$ day/night temperatures with a 16-hour light $\left(700 \mu \mathrm{E} \mathrm{m}^{-2} \mathrm{~s}^{-1}\right.$ photosynthetic photon flux density) and 8-hour dark photoperiod. The humidity regimes chosen simulate the often high but rapidly fluctuating conditions found in eastern North Dakota and the relatively dry conditions in western North Dakota or during dry growing conditions.

Plants were sprayed and then treated with ${ }^{14} \mathrm{C}$-fluroxypyr as described previously and were returned immediately to the growth chambers. Treated plants were transferred between growth chambers to achieve the following posttreatment humidity regimes: 72 hours at low humidity; 1 hour at high followed by 71 hours at low humidity; 6 hours at high followed by 66 hours at low humidity; 24 hours at high followed by 48 hours at low humidity; 48 hours at high followed by 24 hours at low humidity; 24 hours at low followed by 48 hours at high humidity; 6 hours at low followed by 66 hours at high humidity; and 72 hours at high humidity. Plants were harvested 72 hours after treatment and assayed as previously described.

\section{Temperature}

Plants in the late-vegetative growth stage were transferred from the greenhouse to growth chambers 48 hours prior to treatment. Growth chamber conditions were either high $\left(26 / 20^{\circ} \mathrm{C}\right.$ day/night $)$ or low $\left(18 / 14^{\circ} \mathrm{C}\right.$ day/night) temperatures with a 15 hours photoperiod and 50 to $60 \%$ relative humidity. This temperature regime is the general daily mean high temperature range in June in North Dakota, the usual treatment period. Plants were treated, then harvested either 24, 48, 96, and 168 hours after treatment, and assayed as previously described.

\section{Herbicide combinations}

Combination treatments of picloram or 2,4-D with fluroxypyr, have shown increased leafy spurge control compared to fluroxypyr alone $(3,10)$. The effect of combinations of picloram, 2,4-D, and fluroxypyr on absorption and translocation in leafy spurge was evaluated. Picloram potassium salt, 2,4-D alkanolamine salt or fluroxypyr 1-methylheptyl ester were applied alone or in combination to leafy spurge plants in the late-vegetative growth stage. Approximately $1700 \mathrm{~Bq}$ of uniformly pyridyl-ring-labeled ${ }^{14} \mathrm{C}$-picloram (specific activity $623 \mathrm{MBq} \mathrm{mmole}^{-1}$ ) or $1700 \mathrm{~Bq}$ of uniformly phenol-ring-labeled ${ }^{14} \mathrm{C}-2,4-\mathrm{D}$ (specific activity $2035 \mathrm{MBq} \mathrm{mmole}^{-1}$ ) were applied alone or with fluroxypyr as previously described. The treatments consisted of ${ }^{14} \mathrm{C}$-fluroxypyr, ${ }^{14} \mathrm{C}$-fluroxypyr plus picloram, ${ }^{14} \mathrm{C}$-fluroxypyr plus $2,4-\mathrm{D},{ }^{14} \mathrm{C}$-picloram plus fluroxypyr, ${ }^{14} \mathrm{C}$-2,4-D plus fluroxypyr, ${ }^{14} \mathrm{C}$-picloram, and ${ }^{14} \mathrm{C}-2,4-\mathrm{D}$. The labeled herbicides were combined with unlabeled herbicide plus $0.125 \%$ by volume nonionic surfactant ${ }^{6}$ in $10 \mu l$ to achieve an application rate equivalent of fluroxypyr at $0.56 \mathrm{~kg} \mathrm{ha}^{-1}$, picloram at $0.56 \mathrm{~kg} \mathrm{ha}^{-1}$ and 2,4-D at $1.1 \mathrm{~kg} \mathrm{ha}^{-1}$. Plants were harvested 72 hours after treatment, and ${ }^{14} \mathrm{C}$ absorption and translocation were determined as previously described. 


\section{Statistical analyses}

All experiments were conducted three times and had similar variance, so the combined data are presented. All experiments were in a randomized complete block design except the temperature experiment which was a factorial arrangement of temperature and time after treatment. Treatments were replicated four times. The data were subjected to analysis of variance and means were separated using a protected LSD test.

\section{Results and discussion}

\section{Growth stage}

Vegetative leafy spurge absorbed $39 \%$ of applied ${ }^{14} \mathrm{C}$-fluroxypyr compared to 25 and $24 \%$ when leafy spurge was in the flowering or postflowering growth stages, respectively (Table. 1). Also, the ${ }^{14} \mathrm{C}$ concentration in each plant part was or tended to be higher when leafy spurge was treated in the vegetative compared to flowering or postflowering growth stages. For example, the ${ }^{14} \mathrm{C}$-fluroxypyr concentration in leafy spurge roots of vegetative plants was over $490 \mathrm{kBq} \mathrm{g}^{-1}$ compared to 150 and $110 \mathrm{kBq} \mathrm{g}^{-1}$ when ${ }^{14} \mathrm{C}$-fluroxypyr was applied during the flowering and postflowering growth stages, respectively. There was no difference in ${ }^{14} \mathrm{C}$-fluroxypyr concentration by root depth so data were combined in all experiments.

Although the ${ }^{14} \mathrm{C}$-fluroxypyr concentration in leafy spurge roots was highest when applied in the vegetative growth stage, percent of applied herbicide translocated to roots was similar regardless of growth stage (Table 1). In contrast, picloram translocation to leafy spurge roots was greatest during flowering and seed-set growth stages (11). Occasionally, fluroxypyr has provided better leafy spurge control than picloram during the seed-set growth stage (17), especially during drought conditions (8). However, control with fluroxypyr generally has been similar or slightly less than picloram at comparable use rates when applied at other growth stages $(1,2,8)$. Perhaps fluroxypyr is absorbed better than picloram in drought conditions, since fluroxypyr is an ester formulation that may penetrate the cuticle better than picloram which is a potassium salt.

Table 1. Influence of growth stage on ${ }^{14} \mathrm{C}$-fluroxypyr absorption and translocation in leafy spurge 72 hours after treatment.

\begin{tabular}{|c|c|c|c|c|c|c|}
\hline \multirow[b]{2}{*}{ Growth stage } & \multicolumn{6}{|c|}{${ }^{14} \mathrm{C}$ detected in each plant section } \\
\hline & ${ }^{14} \mathrm{C}$ Absorbed & Treated leaf & $\begin{array}{l}\text { Above treated } \\
\text { leaf }\end{array}$ & Below treated leaf & Root & $\begin{array}{l}\text { Total }{ }^{14} \mathrm{C} \text { to } \\
\text { root }\end{array}$ \\
\hline & $\%$ of applied & 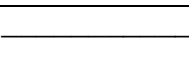 & $\mathrm{kBq} q$ & $\mathrm{~g}^{-1} \mathrm{dwt}$ & 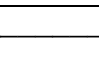 & $\%$ of applied \\
\hline Vegetative & 39 & 204000 & 650 & 420 & 490 & 1.9 \\
\hline Rowering & 25 & 108000 & 260 & 250 & 150 & 1.7 \\
\hline Postflowering & 24 & 60000 & 170 & 90 & 110 & 1.7 \\
\hline $\operatorname{LSD}(0.05)$ & 8 & 120000 & 460 & 250 & 230 & NS \\
\hline
\end{tabular}

Page 5 of 9 


\section{Humidity}

Absorption and translocation of ${ }^{14} \mathrm{C}$-fluroxypyr increased as time at high humidity increased and generally was greatest when them was 48 hours or more of posttreatment high humidity (Table 2). Absorption increased from an average of $38 \%$ with 0 to 1 hour posttreatment high humidity to $53 \%$ with 6 to 72 hours posttreatment high humidity. Translocation of fluroxypyr to plant sections below the treated leaf and to roots was greatest when plants were placed in high humidity for 48 hours followed by low humidity for 24 hours and averaged 7.1 and $5.2 \%$ of applied ${ }^{14} \mathrm{C}$, respectively. Less ${ }^{14} \mathrm{C}$-fluroxypyr was translocated to roots and to stems below the treated leaf when plants were kept at high humidity for 24 hours or less. In general, ${ }^{14} \mathrm{C}$-fluroxypyr absorption was similar for plants placed in high humidity immediately after treatment or following 6 to 24 hours at low humidity, but translocation to roots declined as time at low humidity increased.

Table 2. Influence of posttreatment humidity on ${ }^{14} \mathrm{C}$-fluroxypyr absorption and translocation in leafy spurge 72 hours after treatment. ${ }^{\text {a }}$

\begin{tabular}{|c|c|c|c|c|c|c|c|}
\hline \multicolumn{3}{|c|}{ Posttreatment relative humidity } & \multirow[b]{2}{*}{$\begin{array}{c}{ }^{14} \mathrm{C} \\
\text { Absorbed }\end{array}$} & \multicolumn{4}{|c|}{${ }^{14} \mathrm{C}$ detected in each plant section } \\
\hline High & Low & High & & Treated leaf & $\begin{array}{c}\text { Above } \\
\text { treated leaf }\end{array}$ & $\begin{array}{c}\text { Below } \\
\text { treated leaf }\end{array}$ & Root \\
\hline \multicolumn{3}{|c|}{$\longrightarrow \mathrm{h}-$} & \multicolumn{5}{|c|}{$\%$ of applied } \\
\hline- & 72 & 0 & 39 & 30 & 5.3 & 2.2 & 1.8 \\
\hline 1 & 71 & - & 36 & 24 & 8.0 & 2.1 & 2.2 \\
\hline 6 & 66 & - & 49 & 36 & 7.6 & 2.9 & 2.0 \\
\hline 24 & 48 & - & 50 & 32 & 7.9 & 3.8 & 2.2 \\
\hline 48 & 24 & - & 56 & 34 & 9.3 & 7.1 & 5.2 \\
\hline- & 24 & 48 & 63 & 50 & 5.8 & 3.8 & 3.3 \\
\hline- & 6 & 66 & 52 & 41 & 6.3 & 2.8 & 2.3 \\
\hline- & 0 & 72 & 47 & 36 & 5.2 & 3.1 & 2.8 \\
\hline $\operatorname{LSD}(0.05)$ & & & 14 & 12 & NS & 2.7 & 1.8 \\
\hline
\end{tabular}

${ }^{a}$ Plants were preconditioned at $30 / 18^{\circ} \mathrm{C}$ day/night temperatures and high (90 to $\left.95 \%\right)$ or low (20 to $\left.30 \%\right)$ relative humidity 24 hours before treatment.

Then results are similar to ${ }^{14} \mathrm{C}$-picloram absorption and translocation in leafy spurge which increased as tune at high humidity after treatment increased from 0 to 48 hours (13). However, in that study ${ }^{14} \mathrm{C}$-picloram accumulated in the shoot more than the root as time at high humidity increased compared to ${ }^{14} \mathrm{C}$-fluroxypyr which tended to increase in the below treated led and root sections as posttreatment time at high humidity increased. Thus, to optimize leafy spurge control in the field, fluroxypyr should be applied when the humidity is either already high and expected to remain high or when the relative humidity is expected to increase, such as late in the day. Application under these conditions would maximize fluroxypyr absorption and translocation to roots. 


\section{Temperature}

Absorption of ${ }^{14} \mathrm{C}$-fluroxypyr was similar at 18 and $24^{\circ} \mathrm{C}$ averaging 34 and $33 \%$ of applied ${ }^{14} \mathrm{C}$, respectively (Table 3 ). Most of the absorbed herbicide remained in the treated leaf. An average of 1.1 and $1.4 \%$ of applied ${ }^{14} \mathrm{C}$ moved to the below treated led and root sections, respectively, and was not affected by temperature. In contrast, absorption of ${ }^{14} \mathrm{C}$-picloram increased $1 \%$ for each $1^{\circ} \mathrm{C}$ increase in temperature, but translocation to the root system declined as temperature increased (11). Occasional poor leafy spurge control may be due to application during periods of temperature fluctuation adverse to picloram absorption and translocation.

Table 3. Influence of temperature on ${ }^{14} \mathrm{C}$-fluroxypyr absorption and translocation in leafy spurge at four times after treatment.

\begin{tabular}{|c|c|c|c|c|c|c|}
\hline \multirow[b]{2}{*}{ Temperature } & \multirow[b]{2}{*}{$\begin{array}{l}\text { Time after } \\
\text { treatment }\end{array}$} & \multirow[b]{2}{*}{$\begin{array}{l}\text { Total }{ }^{14} \mathrm{C} \\
\text { absorbed }\end{array}$} & \multicolumn{4}{|c|}{${ }^{14} \mathrm{C}$ detected in each plant section } \\
\hline & & & Treated leaf & $\begin{array}{c}\text { Above } \\
\text { treated leaf }\end{array}$ & $\begin{array}{l}\text { Below } \\
\text { treated leaf }\end{array}$ & Root \\
\hline $\mathrm{C}$ & $\mathrm{h}$ & - & +3 & $\%$ of applied & 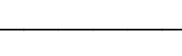 & 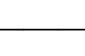 \\
\hline 18 & 24 & 44 & 42 & 0.8 & 0.6 & 1.0 \\
\hline 18 & 48 & 31 & 27 & 1.1 & 1.0 & 2.2 \\
\hline 18 & 96 & 28 & 25 & 1.1 & 0.8 & 1.5 \\
\hline 18 & 168 & 31 & 26 & 2.1 & 1.0 & 1.4 \\
\hline 24 & 24 & 31 & 26 & 2.0 & 1.9 . & 1.3 \\
\hline 24 & 48 & 35 & 31 & 1.9 & 0.9 & 1.2 \\
\hline 24 & 96 & 37 & 30 & 4.5 & 1.2 & 1.1 \\
\hline 24 & 168 & 30 & 24 & 3.6 & 1.1 & 1.1 \\
\hline $\operatorname{LSD}(0.05)$ & & NS & 10 & 1.3 & NS & NS \\
\hline \multicolumn{7}{|c|}{ Mean (Temperature) } \\
\hline 18 & - & 34 & 30 & 1.3 & 0.9 & 1.5 \\
\hline 24 & - & 33 & 28 & 3.0 & 1.3 & 1.2 \\
\hline $\operatorname{LSD}(0.05)$ & & NS & NS & 1.0 & NS & NS \\
\hline
\end{tabular}

\section{Herbicide combinations}

Absorption and translocation of ${ }^{14} \mathrm{C}$-fluroxypyr to all plant parts usually was greater when applied alone than when applied with picloram or 2,4-D (Table 4). Absorption averaged $48 \%$ when applied alone compared to 35 and $24 \%$ when applied with picloram or 2,4-D. However, absorption and translocation of ${ }^{14} \mathrm{C}$-picloram or ${ }^{14} \mathrm{C}-2,4-\mathrm{D}$ was not reduced when applied with fluroxypyr.

Absorption and translocation of ${ }^{14} \mathrm{C}$-fluroxypyr and ${ }^{14} \mathrm{C}-2,4-\mathrm{D}$ generally, were similar and usually were at least three-fold that for ${ }^{14} \mathrm{C}$-picloram in leafy spurge (Table 4). Ab- 
sorption of ${ }^{14} \mathrm{C}$-picloram averaged $13 \%$ compared to 48 and $36 \%$ with ${ }^{14} \mathrm{C}$-fluroxypyr or ${ }^{14} \mathrm{C}-2,4-\mathrm{D}$ respectively. These results are similar to previous research with ${ }^{14} \mathrm{C}-2,4-\mathrm{D}$ and ${ }^{14} \mathrm{C}$-picloram absorption in leafy spurge (13).

Increased control obtained with fluroxypyr when applied in combination with 2,4-D or picloram compared to each herbicide applied alone apparently is not due to increased absorption or translocation of the herbicides. Increased control may be due to decreased herbicide metabolism. For example, picloram applied with 2,4-D resulted in both decreased picloram and 2,4-D metabolism and greater leafy spurge control than when the herbicides were applied alone (9). Fluroxypyr metabolism in leafy spurge may also decline when applied with 2,4-D or picloram especially since fluroxypyr and picloram have similar chemical structures and likely would be metabolized similarly by leafy spurge. However, fluroxypyr metabolism was not studied in these experiments.

Table 4. Absorption and translocation of ${ }^{14} \mathrm{C}$-fluroxypyr, ${ }^{14} \mathrm{C}$-picloram, and ${ }^{14} \mathrm{C}-2,4-\mathrm{D}$ in leafy spurge when applied alone and with other herbicides evaluated 72 hours after treatment.

\begin{tabular}{|c|c|c|c|c|c|}
\hline \multirow[b]{2}{*}{ Treatment } & \multirow[b]{2}{*}{$\begin{array}{l}\text { Total }{ }^{14} \mathrm{C} \\
\text { absorbed }\end{array}$} & \multicolumn{4}{|c|}{${ }^{14} \mathrm{C}$ detected in each plant section } \\
\hline & & Treated leaf & $\begin{array}{c}\text { Above treated } \\
\text { leaf }\end{array}$ & $\begin{array}{c}\text { Below treated } \\
\text { leaf }\end{array}$ & Root \\
\hline \multicolumn{6}{|c|}{$\%$ of applied } \\
\hline${ }^{14} \mathrm{C}$-fluroxypyr & 48 & 38 & 4.6 & 3.3 & 2.1 \\
\hline${ }^{14} \mathrm{C}$-fluroxypyr plus picloram & 35 & 26 & 5.0 & 2.4 & 1.7 \\
\hline${ }^{14} \mathrm{C}$-fluroxypyr plus $2,4-\mathrm{D}$ & 24 & 18 & 2.8 & 1.6 & 1.4 \\
\hline${ }^{14} \mathrm{C}$-picloram & 13 & 12 & 0.5 & 0.2 & 0.5 \\
\hline${ }^{14} \mathrm{C}$-picloram plus fluroxypyr & 11 & 7 & 3.1 & 0.8 & 0.6 \\
\hline${ }^{14} \mathrm{C}-2,4-\mathrm{D}$ & 36 & 30 & 1.8 & 2.5 & 1.9 \\
\hline${ }^{14} \mathrm{C}-2,4-\mathrm{D}$ plus fluroxypyr & 38 & 34 & 1.7 & 1.4 & 1.2 \\
\hline $\operatorname{LSD}(0.05)$ & 22 & 22 & 0.2 & 1.0 & 0.6 \\
\hline
\end{tabular}

Picloram will likely remain the herbicide of choice for leafy spurge control because it is more toxic to leafy spurge than fluroxypyr or 2,4-D. Nearly four times as much fluroxypyr and 2,4-D are translocated to leafy spurge roots than picloram, yet picloram provides better long-term control than the other herbicides. Thus, 2,4-D and fluroxypyr are probably less active in leafy spurge than picloram. Based on these laboratory data which indicate that fluroxypyr enters and is translocated in leafy spurge better than picloram but field data which indicates it is generally less effective, fluroxypyr likely will be of minor importance in a leafy spurge control program. Fluroxypyr would be useful in special circumstances such as very cool or hot temperatures or dry growing conditions when picloram is less effective, or in an area with a high water table where picloram cannot be used. 


\section{Acknowledgments}

The author gratefully acknowledges the financial support for this project from the Dow Chemical Company who also supplied the ${ }^{14} \mathrm{C}$-fluroxypyr and ${ }^{14} \mathrm{C}$-picloram and the technical assistance of Katheryn Christianson.

\section{Literature cited}

1. Beck, K. G., J. R. Sebastian, and D. E. Hanson. 1989. Leafy spurge control with fluroxypyr, picloram, and 2,4-D on Colorado rangeland. Pages 9-10 in Res. Prog. Rep. West. Soc. Weed Sci.

2. Becker, R. L. and D. F. Ralston. 1989. Leafy spurge control in 1989 with 1988 applications of sulfometuron, picolinic acid derivatives, and commercial standards. Res. Rep. North Cent. Weed Sci. Soc. 46:102.

3. Ferrell, M. A. and T. D. Whitson. 1989. Fluroxypyr in combination with various herbicides for leafy spurge control Page 64 in Res. Prog. Rep. West. Soc. Weed Sci.

4. Gylling, S.R. and W. S. Arnold. 1985. Efficacy and economics of leafy spurge (Euphorbia esula) control in Pastures. Weed Sci. 33:381-385.

5. Lym, R.G. and C. G. Messersmith. 1985. Leafy spurge control with herbicides in North Dakota: 20-year summary. J. Range. Manage. 38:149-154.

6. Lym, R.G. and C. G. Messersmith. 1985. Leafy spurge control and improved forage production with herbicides. J. Range. Manage. 39:386-391.

7. Lym, R.G. and C. G. Messersmith. 1988. Survey for picloram in North Dakota groundwater. Weed Technol. 2:217-222.

8. Lym, R. G. and C. G. Messersmith. 1988. Fluroxypyr alone and with auxin herbicides for leafy spurge control. Res. Rep. North Cent. Weed Control Conf. 45:88.

9. Lym, R. G. and K. D. Moxness. 1989. Absorption, translocation, and metabolism of picloram and 2,4-D in leafy spurge (Euphorbia esula). Weed Sci. 37:498-502

10. Lym, R.G. and C. G. Messersmith. 1990. Fluroxypyr alone and with auxin herbicides applied annually for 3 years to control leafy spurge Page 8 in Res. Prog. Rep. West. Soc. Weed Sci.

11. Lym, R.G. and C. G. Messersmith. 1990. Effect of temperature on picloram absorption and translocation in leafy spurge (Euphorbia esula). Weed Sci. 38:471-474.

12. Messersmith, C. G. and R. G. Lym. 1983. Distribution and economic impact of leafy spurge in North Dakota. ND. Farm Res. 40(5):3-7.

13. Moxness, K. D. and R. G. Lym. 1989. Environment and spray additive effects on picloram absorption and translocation in leafy spurge (Euphorbia esula). Weed Sci. 37:181-186.

14. Shober, A. E., S. A. McMaster, and R. L. Gantz. 1986. Fluroxypyr: A new environmentally compatible herbicide. Pages 167-168 in Res. Prog. Rep. West. Soc. Weed Sci.

15. Thompson, F. 1990. Economic Impact of leafy spurge on North Dakota grazing land M.S. Thesis, North Dakota State Univ., Fargo. 99 p.

16. Weed Science Society America. 1989. Herbicide Handbook, sixth ed. Champaign, IL.

17. Whitson, T. D. 1986. Comparative treatments of fluroxypyr, dicamba, and picloram for leafy spurge control. Page 41 in Res. Prog. Rep. West. Soc. Weed Sci.

Page 9 of 9 